\section{Consequences of smoking during pregnancy for mother and child}

\section{Efeitos do tabagismo na gestação para a mãe e para a criança}

\author{
Gustavo Horacio Marin 1 \\ Liliana Delgado 2 \\ Gustavo Sager 3 \\ Silvana Visentín 4 \\ Sebastiana Azzaro 5 \\ Mabel Tozzi 6
}

1,3-6 Serviço de Hematología. Hospital Internazonal General de Agudos Gral San Martín. Ministério de Salud de la Provincia de Buenos Aires. Calle 1 y 70, (1900). La Plata, Buenos Aires, Argentina.

2 Facultad de Ciencias Médicas. Universidad Nacional de La Plata, Buenos Aires, Argentina.

\begin{abstract}
Objective: to evaluate the consequences of maternal smoking

Methods: a prospective study of 1.103 pregnant women. A survey in the state Hospital San Martin, de La Plata, Buenos Aires determined general data. Newborn and placenta data were also reported. Mother and child cord samples were obtained to determine blood elements and flow cytometry analysis of lymphocyte subsets performed. Data from smoking (S) and non-smoking (NS) groups were evaluated through relative risk, chi square and Student's t test.

Results: of all patients, 887 were NS and 226 said they smoked over five-cigarettes/day (S). The $S$ group showed a higher probability of premature deliveries when compared to the NS group, with newborns weighing under $2,5 \mathrm{~kg}$, small in relation to gestational age, with Apgar scores at the 5th minute under six and hyaline membrane syndrome; intrauterine death risk was higher in this group who attended less medical appointments than scheduled. Umbilical cord blood analysis indicated lower reticulocyte index for $S$ mothers, neutrophil count and CD4/CD8 ratio and increased erythroblast, eosinophil, basophil, total and CD8+T lymphocyte counts.

Conclusions: data could explain the observations by other authors related to an increased incidence of allergy and infections in newborns caused by maternal smoking.
\end{abstract}

Key words Pregnancy, Smoking

\section{Resumo}

Objetivos: avaliar as conseqüências para a mãe e para o filho do hábito de fumar durante a gestação.

Métodos: é um estudo prospectivo com 1.103 gestantes a partir de inquérito em mulheres atendidas no Hospital San Martin de La Plata, Buenos Aires. Amostras foram obtidas para determinação de elementos sangüineos e citometria de fluxo. O risco relativo entre fumantes e não fumantes foi calculado e se usou ainda o $\chi^{2}$ e o teste " $t$ " de Student.

Resultados: 887 gestantes eram não fumantes $e$ 226 não fumantes. O grupo fumante teve maior probalidade do que o não fumante para: partos prematuros, recém-natos com peso baixo, pequenos em relação à idade gestacional, maior risco de morte intra-uterina, Apgar abaixo de seis aos cinco minutos, sindrome da membrana hialina, menor número de consultas do que as programadas. $A$ análise do sangue do cordão umbelical mostrou nas fumantes: menor número de reticulocitos, diminuição da relação CD4/CD8 e maior número de eritroblastos, eosinófilos, basófilos, linfócitos totais e CD8.

Conclusões: os dados poderiam explicar observações de outros autores indicando maior incidência de alergias e infecções em recém-natos causadas por tabagismo materno.

Palavras-chave Gravidez, Tabagismo 


\section{Introduction}

There is strong evidence indicating the relationship between tobacco and: cancer, heart, vascular or lung diseases driving authorities of many countries to implement sanitary policies such as the prohibition of smoking in certain public spaces (inside airplanes, museums, etc) all over the world.

However, smoking remains an individual choice for it is not possible to restrict the habit in private environments as one's own home. Health campaigns against tobacco are overwhelmed by tobacco industries'investments.

Smoking is extremely costly for all governments that annually spend millions of dollars treating tobacco's related diseases. A clear example of this has been published by the National Hospital Discharge Survey (NHDS), reporting the expenses incurred by private health insurance companies in the United States of America at 167 million dollars annually to treat tobacco ${ }^{1}$ related complications.

Smoking, notwithstanding being detrimental to health, it is, as previously mentioned, a personal choice. Nevertheless, there are two situations impacting the health of others: a) one is the case of passive smokers, for smokers contaminate the air surrounding them, forcing others to inhale it. This can be avoided by restricting smoking to specific areas or by prohibiting smoking in certain environments, etc; b) a more severe situation when compared to the previous one is when "passive" smokers have no way out and are forced to live and breathe in the same environment. That is the case of babies when their mothers continue smoking during pregnancy.

Smoking during pregnancy has being associated to complications such as previous placenta, ${ }^{2}$ placenta's detachments, ${ }^{3}$ and undersized newborns. $4,5 \mathrm{~A}$ prospective study was carried out in pregnant smoking and non-smoking mothers and their children, with the purpose of determining the effects of smoking during pregnancy.

\section{Methods}

A survey was accomplished during the time of pregnancy diagnosis to determine what patients should be included in the study.

1.103 pregnant women attending to State Hospital San Martín of La Plata, Ministry of Health, Buenos Aires, Argentina were included in a prospective study between April and August of 1999. They were clinically followed up until January 2002.
The group was comprised of patients daily smoking five cigarettes or more during pregnancy. Exclusion criteria were known prior pathology (arterial hypertension, diabetes) and other conditions detected by the initial control such as severe anemia $(<9 \mathrm{gr} / \mathrm{dl})$, and women in any kind of drugs other than nutrition supplements prescribed by the status' nutritional therapy.

The data requested was age, initial weight, whether the respondents were smokers or nonsmokers and amount of cigarettes consumed daily. At parturition's time, a new survey was accomplished to confirm whether or not the women had continued smoking during the course of pregnancy, as well as the daily quantity of cigarettes consumed.

Weight at delivery time, gestational age, Apgar score of the new born at the first and five minutes after birth, baby's weight, and placenta's weight were some of the analyzed data. Cord blood samples from smoking and non-smoking mothers were analyzed by a double blind laboratory method. From each sample, the following information was collected: hematocrite, hemoglobin, red cells, reticulocytes and leukocytes recounts, leukocyte subtypes formula, platelets recount, T and B lymphocytes subtype, natural killer (NK) absolute number of cells CD3, CD4, CD8, CD19, CD3-/CD56+ (NK) and CD4/CD8 ratios. Erythrocytes, leukocytes and platelets tests were performed through an automatic cellular counter (Microcell counter Sysmex F-803), hematocrites were confirmed by reticulocyte microcentrifuge, dyeing was performed by crescile blue brilliant and for the leukocitary formula smear analysis was performed by optic microscopy. The following panel was used to determine the sub-types of lymphocyte in the samples: g1/g1, CD3/CD4, CD3/CD8, CD3/CD56, CD19, all were conjugated with fluorescein or pico-erythryn (FITC or PE) and posterior flowcytometry reading (Coulter Epics XL). For the analysis of patient's and newborn's data, the perinatal computer system from the Pan-American Health Organization (PAHO) and World Health Organization (WHO) was used. Relative risk and chi square values were used to establish the different variable ratios of both groups (smoking and nonsmoking mothers), the confidence interval used was of $(95 \% \mathrm{CI})$. For the assessment of numerical hematological and immunological variables the $t$ Student test was used to compare the groups of smoking and non-smoking mothers and their babies. For variables' homogeneity testing the Barlett's chi square test was used. 


\section{Results}

Of the 1.103 patients in the study, 877 were included in the non-smoking group (NS) and 226 in the smoking group (S).

Only $2,58 \%$ of the smoking patients at the time pregnancy was diagnosed, ceased smoking during the course of pregnancy.
Patients age was of $26,04( \pm 6,48)$ in the NS group and $24,55( \pm 6,52)$ in the $S$ group. Patients'average weight was of 69,96 kilograms $( \pm 12,47)$ and 69,32 $( \pm 11,6)$ respectively $(\mathrm{p}=0,56)$.

The number of medical visits attended were less than the five visits scheduled in $64,06 \%$ in $\mathrm{S}$ group and $50,05 \%$ in non-smoking group (Table 1).

Table 1

Relative frequency and relative risk of variables.

\begin{tabular}{|c|c|c|c|c|c|c|}
\hline Variable & S (\%) & NS (\%) & Relative risk & $95 \% \mathrm{Cl}$ & $\chi^{2}$ & $\mathbf{p}$ \\
\hline Inadequate weight for gestational age & 18,30 & 9,56 & 1,92 & $1,34-2,07$ & 8,7 & 0,003 \\
\hline Premature delivery threat & 4,78 & 3,93 & 0,82 & $0,64-2,39$ & 0,2 & 0,672 \\
\hline Intrauterine death & 5,46 & 1,23 & 2,23 & $1,27-6,33$ & 11,9 & 0,004 \\
\hline Number of medical visits during gestation $<5$ & 64,06 & 50,05 & 1,28 & $1,14-1,44$ & 8,9 & 0,003 \\
\hline Newborn's weight at birth $(<2.500 \mathrm{~g})$ & 19,20 & 7,62 & 2,93 & $2,03-4,23$ & 18,2 & 0,001 \\
\hline Apgar at first minute $<6$ & 4,09 & 3,79 & 2,02 & $1,58-9,77$ & 0,0 & 0,803 \\
\hline Apgar at fifth minute $<6$ & 2,45 & 0,31 & 7,69 & $1,57-27,17$ & 8,9 & 0,022 \\
\hline Hyaline membrane syndrome in newborn & 2,47 & 0,21 & 11,77 & $2,39-57,95$ & 11,9 & 0,012 \\
\hline Respiratory distress & 5,78 & 4,19 & 1,38 & $0,75-2,55$ & 0,7 & 0,420 \\
\hline $\begin{array}{l}\text { Hemorrhages during the } 3^{\text {rd }} \text { trimester of } \\
\text { pregnancy }\end{array}$ & 0,78 & 0,72 & 1,08 & $0,27-6,44$ & 0,0 & 1,000 \\
\hline Congenital anomalies & 3,30 & 1,67 & 1,97 & $0,76-4,44$ & 1,6 & 0,269 \\
\hline
\end{tabular}

NS = Non-smokers $\mathbf{S}=$ Smokers ( $>5$ cigarettes per day) .

Gestational age was younger in $\mathrm{S}$ than in NS ( $p<0,001)$ while the risk of intrauterine death was highly increased in the smoking mothers $(p=0,004)$.

The average weight of the placenta was of $539,21( \pm 117,50)$ in $S$ and of 561,96 $( \pm 127,59)$ in NS $(\mathrm{p}=0,046)$.

Mothers exposed to tobacco had an increased risk of delivering babies under $2.500 \mathrm{mg}$ ( $\mathrm{p}<0,001$ ).

The ratio of new-born weight and gestational age was also smaller in the group of smokers when compared to the NS group $(\mathrm{p}=0,003)$.

An Apgar score under six points at the first minute after birth was the same for both groups in the study, however, when the test was applied after five minutes, a higher risk of Apgar values under six in smoking mothers'babies was determined $(p=0,02)$.

Hyaline membrane syndrome was predominantly seen in smoking mothers' babies $(p=0,012)$, howe- ver, no differences were determined concerning other types of breathing distress $(\mathrm{p}=0,420)$.

The samples of umbilical cord blood from pregnant smokers (Tables 2 and 3), showed less neutrophiles $(\mathrm{p}<0,001)$ and reticulocytes $(\mathrm{p}<0,001)$, and a higher eosinophiles percentage $(\mathrm{p}<0,001)$, lymphocyte ( $p<0,001)$, basophifils $(p<0,001)$ and of erythroblasts $(\mathrm{p}<0,001)$ compared to cord blood from NS mothers. A decrease in the percentage of the CD4+ lymphocytes ( $p<0,001)$ and an increase of the CD8+ $(\mathrm{p}<0,001)$, with a diminished CD4/CD8 relationship ( $\mathrm{p}<0,001)$ in the $\mathrm{S}$ cord blood samples (Table 4) was determined as well. However, absolute CD4 values in both groups did not show any difference $\left[2.039 / \mathrm{mm}^{3}\right.$ vs. S: $\left.1.944 / \mathrm{mm}^{3}(\mathrm{p}=0,390)\right]$ while CD8 values were higher in $\mathrm{S}$ than in NS [1.173 vs. $1.592(\mathrm{p}<0,001)]$. 
Table 2

General haematological data $\left(\bar{X} \pm S D^{*}\right)$ referring to umbilical cord blood.

\begin{tabular}{|c|c|c|c|c|c|c|c|}
\hline Group & $\begin{array}{c}\text { Hematocrite } \\
(\%)\end{array}$ & $\begin{array}{l}H b * * \\
(G / d I)\end{array}$ & $\begin{array}{c}\text { Reticulocytes } \\
(\%)\end{array}$ & $\begin{array}{c}\text { Erythroblasts } \\
(\%)\end{array}$ & $\begin{array}{l}\text { Red Blood Cell } \\
\left(\times 106 / \mathrm{mm}^{3}\right)\end{array}$ & $\begin{array}{c}\text { Platelets } \\
\left(\times 10^{3} / \mathrm{mm}^{3}\right)\end{array}$ & $\begin{array}{l}\text { Leukocytes } \\
\left(\mathrm{X} 10^{3} / \mathrm{mm}^{3}\right)\end{array}$ \\
\hline Non-smokers & $44,82 \pm 5,11$ & $14,59 \pm 0,94$ & $4,07 \pm 1,44$ & $2,74 \pm 3,12$ & $4,74 \pm 0,77$ & $257,86 \pm 55,29$ & $11,63 \pm 3,71$ \\
\hline Smokers & $45,08 \pm 5,56$ & $14,40 \pm 0,91$ & $3,21 \pm 2,05$ & $15,72 \pm 6,02$ & $5,97 \pm 4,56$ & $245,50 \pm 43,54$ & $11,64 \pm 3,38$ \\
\hline $\mathrm{p}$ & $=0,583$ & $=0,025$ & $<0,001$ & $<0,001$ & $=0,332$ & $=0,005$ & $=0,975$ \\
\hline
\end{tabular}

Normal values (data for our hospital standards in 1997): Hematocrite: $47,62( \pm 7,41)$; Hemoglobine (hb): $15,64( \pm 4,04)$; Reticulocytes: $3,6( \pm 1,7)$; Erythroblast: 3,44 ( $\pm 3,24)$; Red blood: 4,99 $( \pm 3,12)$; Platelets: $264,44( \pm 60,34)$; Leukocytes: $12,72( \pm 6,22)$.

Table 3

Haematological data $(\bar{X} \pm S D)$ referring to leukocyte differential count in umbilical cord blood.

\begin{tabular}{|c|c|c|c|c|c|c|c|c|c|c|}
\hline \multirow{2}{*}{ Group } & \multicolumn{2}{|c|}{ Neutrophils } & \multicolumn{2}{|c|}{ Eosinophils } & \multicolumn{2}{|c|}{ Basophils } & \multicolumn{2}{|c|}{ Lymphocytes } & \multicolumn{2}{|c|}{ Monocytes } \\
\hline & $\%$ & $\mathrm{X} 10^{3} / \mathrm{mm}^{3}$ & $\%$ & $\mathrm{X} 10^{3} / \mathrm{mm}^{3}$ & $\%$ & $\mathrm{X} 10^{3} / \mathrm{mm}^{3}$ & $\%$ & $\mathrm{X} 103 / \mathrm{mm}^{3}$ & $\%$ & $\mathrm{X} 103 / \mathrm{mm} 3$ \\
\hline Non-smokers & $57,40 \pm 6,15$ & $6,68 \pm 2,26$ & $0,45 \pm 0,97$ & $0,05 \pm 0,11$ & $0,03 \pm 0,21$ & $0,003 \pm 0,02$ & $40,63 \pm 5,80$ & $4,71 \pm 1,59$ & $1,49 \pm 2,06$ & $0,18 \pm 0,32$ \\
\hline Smokers & $48,63 \pm 6,70$ & $5,70 \pm 2,05$ & $5,94 \pm 3,02$ & $0,68 \pm 0,39$ & $0,10 \pm 0,37$ & $0,013 \pm 0,05$ & $43,12 \pm 6,07$ & $5,00 \pm 1,52$ & $2,18 \pm 2,67$ & $0,24 \pm 0,32$ \\
\hline $\mathrm{p}$ & $<0,001$ & $<0,001$ & $<0,001$ & $<0,001$ & $=0,005$ & $=0,009$ & $<0,001$ & $=0,048$ & $=0,021$ & $=0,052$ \\
\hline
\end{tabular}

Normal values (data for our hospital standards in 1997): \%: Neutrophils: $60,22( \pm 6,10)$; Eosinophils: 1,2 ( $\pm 1,19)$; Basophils: 0,07 ( \pm 0,20); Lymphocytes: 39,66 ( $\pm 5,56)$; Monocytes: 2,01 $( \pm 3,31)$.

Table 4

Immunological data $(\bar{X} \pm S D)$ referring to umbilical cord blood.

\begin{tabular}{|c|c|c|c|c|c|c|}
\hline Group & CD3 (\%) & CD4 (\%) & CD8 (\%) & CD4/CD8 (\%) & CD19 (\%) & $N K^{*}(\%)$ \\
\hline Non-smokers & $72,53 \pm 4,41$ & $43,05 \pm 3,98$ & $24,95 \pm 3,75$ & $1,80 \pm 0,42$ & $11,98 \pm 4,43$ & $4,96 \pm 0,80$ \\
\hline Smokers & $73,23 \pm 4,80$ & $38,78 \pm 2,83$ & $31,76 \pm 3,25$ & $1,06 \pm 0,23$ & $11,51 \pm 4,28$ & $4,90 \pm 6,07$ \\
\hline $\mathrm{p}$ & $<0,095$ & $<0,001$ & $<0,001$ & $<0,001$ & $=0,242$ & $=0,059$ \\
\hline
\end{tabular}

Normal values (data for our hospital standards in 1997): \%: CD3: 74,26 ( $\pm 5,12) ; C D 4: 46,28( \pm 5,48) ; C D 8: 26,74( \pm 6,44) ; C D 4 / C D 8$ :

$2,11( \pm 1,84)$; NK: 3,26 $( \pm 4,86) ; * N K$ : Natural killers (CD3-/CD56+). 


\section{Discussion}

Prior studies have shown that maternal smoking during pregnancy causes a higher incidence of previous placenta, ${ }^{2}$ placental detachment, ${ }^{3}$ and low weight newborns.

The association prenatal exposure to tobacco and newborns affected by allergies, 4 asthma,5-8 abnormal lung development, ${ }^{9}$ neonatal lung dysfunctions, 10,11 pulmonary infections, 12 decrease in the Apgar score at the first minute ${ }^{13}$ and increase of sudden death 14 events has been determined. Posterior evaluation of these children has determined that they tend to have concentration impairments in school.15 Aggressive and violent behavior has also been determined in youths and adults whose mothers were smokers. ${ }^{16-18}$

Other authors reported that fetal blood samples from smoking mothers had reduced numbers of neutrophiles, 19 as well as higher erythropoietin levels. 20

Our study confirms some of these tendencies and adds new ones. Data obtained in this study show significant high risk for smoking mothers to deliver premature and underweight babies $(<2.500 \mathrm{mg})$, intrauterine death, small babies in relation to gestational age, Apgar score less than six after five minutes, and hyaline membrane syndromes. It has also been determined that the majority of mothers in the $\mathrm{S}$ group attended less than five medical visits during pregnancy as compared to the NS group. It is possible that these women did not attend medical visits because they were not willing to stop smoking during pregnancy.

Considering neutrophil decrease exists in babies with smoking mothers, it is clear that this will result in certain degree of immunodeficiency, predisposing them to several infections. CD4/CD8 ratio decrease, also observed in cord blood from the $\mathrm{S}$ group, is probably due not only to a decrease in the CD4 cells absolute number, but also to an increment in CD8 levels. The high eosinophils percentage determined in the $\mathrm{S}$ group as opposed to the NS group, ecould be correlated with allergic problems and the lung permeability increase described in these babies.

Considering pregnancy is a period of the life in which women become aware they are no longer by themselves and must look after their babies, it has been proven they are prone to abandon old addictions like tobacco. 21

However, according to our data, only few women from the study gave up smoking during pregnancy. Many times, pregnancy is a good excuse to stop the habit of smoking by the whole family. 21

Controlled studies performed to evaluate programs promoting tobacco abandonment during pregnancy have indicated these are successful.22 Randomized studies, confirm that simple medical advice has been enough to reduce the habit of smoking in over $50 \%$ of pregnant women. ${ }^{23}$ It would be desirable then to use this stage to promote programs encouraging women to quit smoking during pregnancy. 24

\section{Conclusions}

Smoking during pregnancy increases the probability of intrauterine deaths, premature and underweight babies, inadequate weight and gestational period ratio, an Apgar score < six at five minutes and hyaline membrane condition. Smoking mothers attended less medical visits than scheduled during pregnancy. Changes were also detected in: conformation of leucocytes, erithrocytes, and eosinophiles increase, basophiles, lymphocytes and eritroblasts. This could explain the predisposition these children have to infections or complications early in their lives.

Our study determined a very low tendency of pregnant women to quit smoking during pregnancy. A program implemented by health professionals explaining the consequences of smoking during pregnancy could be able to revert this tendency and improve the health of pregnant women and their babies. 


\section{References}

1. Adams EK, Melvin CL. Costs of maternal conditions attributable to smoking during pregnancy. Am J Prev Med 1998; 15: 212-9.

2. Castles A, Adams EK, Melvin CL, Kelsch C, Boulton ML. Effects of smoking during pregnancy: five meta-analyses. Am J Prev Med 1999; 16: 208-15.

4. Ananth CV, Smulian JC, Vintzileos AM. Incidence of placental abruption in relation to cigarette smoking and hypertensive disorders during pregnancy: a meta-analysis of observational studies. Obstet Gynecol 1999; 93: 622-8.

5. Mantzoros C, Varvarigou A, Kaklamani VG, Beratis NG, Flier JS. Effects of birth weight and maternal smoking on cord blood of newborns. J Clin Endocrinol Metab 1997; 82: 2856-61.

6. Das TK, Moutquin JM, Lindsay C, Parent JG, Fraser W. Effects of smoking cessation on maternal airway function and birth weight. Obstet Gynecol 1998; 92: 201-5.

7. Peat J, Bjorkesten B. Primary and secondary prevention of allergic asthma. Eur Respir J 1998; 27 Suppl: 28-34.

8. SIDRIA (Studi Italiani sui Disturbi Respiratori nell' Infanzia e l' Ambiente). Parental smoking, asthma and wheezing in children and adolescents. Epidemiol Prev 1998; 22: 146-54.

9. Marin A, Eseverri J, Botey J. From atopic dermatitis to asthma. Allergol Immunopathol 1998; 26: 114-9.

10. Stein RT, Holberg CJ, Sherrill D, Wright AL, Morgan WJ, Taussig L, Martinez FD. Influence of parental smoking on respiratory symtomps during the first decade of life: the Tucson children's respiratory study. Am J Epidemiol. 1999; 149: 1030-7.

11. Hoo AF, Henschen M, Dezateux C, Costoloe K, Stocks J. Respiratory function among preterm infants whose mothers smoked during pregnancy. Am J Resp Crit Care Med 1998; 158: 700-5.

12. Milner AD, Marsh MJ, Ingram DM, Fox GF, Susiva C. Effects of smoking in pregnancy on neonatal lung function. Arch Dis Child Fetal Neonatal 1999; 80: 8-14.

13. Taylor B, Wadsworth J. Maternal smoking in pregnancy and lower respiratory tract illnes in early life. Arch Dis Child 1987; 62: 786-91.

14. Gibson C, Tibbetts SG. Interaction between maternal cigarette smoking and Apgar scores in predincting offending behavior. Psychol Rep 1998; 83: 579-86.
15. Storm H, Nylander G, Saugstad OD. The amount of brainstem gliosis in sudden infant death syndrome (SIDS) victims correlates with maternal cigarettes smoking during pregnancy. Acta Paediatr 1999; 88: 13-8.

16. Leech SL, Richardson GA, Goldschimdt L, Day NL. Prenatal substance exposure: effects on attention and impulsivity of 6 years olds. Neurotoxicol Teratol 1999; 21: 109-18.

17. Rasanen P, Hakko H, Isohanni M, Hodgins S, Jarvelin MR, Tiihonen J. Maternal smoking during pregnancy and risk of criminal behavior among adult male, offspring in the Northern Finland 1966 Birth Cohort. Am J Psychiatry 1999; 156: 857-62.

18. Brennan P, Grekin ER, Mednick SA. Maternal smoking during pregnancy and adult male criminal outcomes. Arch Gen Psychiatry 1999; 56: 215-9.

19. Orlebeke J, Knol DL, Verhulst FC. Child behavior problems increased by maternal smoking during pregnancy. Arch Environ Health 1999; 54: 15-9.

20. Mercelina-Roumans PE, Breukers RB, Ubachs JM. Hematological variables in cord blood of neonates of smoking and non smoking mothers. J Clin Epidemiol 1996; 49: 449-54.

21. Jazayeri A, Tsibris JC, Spellacy WN. Umbilical cord plasma erythropoietin levels in pregnancies complicated by maternal smoking. Am J Obstet Gynecol 1998; 178: 433-5.

22. Hakansson A, Lendahls L, Peterson C. Which women stop smoking? A population-based study of 403 pregnant smokers. Acta Obstet Gynecol Scand 1999; 78: 217-24.

23. Lowe JB, Balandra KP, Clare G. Evaluation of antenatal smoking cessation programs for pregnant women. Aust NZ J Public Health 1998; 22: 55-9.

24. Secker-Walker RH, Solomon LJ, Flynn BS, Skelly JM, Mead PB. Reducing smoking during pregnancy and postpartum: physician's advice supported by individual counselling. Prev Med 1998; 27: 422-30.

25. Wakerfield M, Reid Y, Roberts L, Mullins P, Gillies P. Smoking and smoking cessation among men whose partners are pregnant, a qualitative study. Soc Sci Med 1998; 47: 657-64.

Recebido em 9 de dezembro de 2002

Versão final reapresentada em 10 de março de 2003

Aprovado para publicação em 7 de abril de 2003 